\title{
In vitro effect of histamine on monocyte chemotaxis
}

\author{
Yoshio Tsukamoto, Kuniko Fukuda, Mutsumi Ishikawa, Mikio Ieiri, \\ Kazuya Uwazumi and Masakazu Mori \\ Department of Pharmacology (Chief: Prof. Masakazu Mori), Osaka Dental University, \\ Kyobashi, Higashi-ku, Osaka 540, Japan
}

[Accepted for publication: April 8, 1982]

Key words: histamine / monocytes / chemotaxis / histamine antagonists

Histamine has been reported to be a selective chemoattractant for eosinophils ${ }^{1,2)}$, to modulate eosinophil migration ${ }^{3}$ and to inhibit basophil chemotaxis ${ }^{4}$ by interacting with $\mathrm{H}_{1}$ - and $\mathrm{H}_{2}$-receptors. Furthermore, neutrophil chemotaxis is inhibited by histamine, an effect associated with elevated levels of intracellular cAMP5). However, the effects of histamine on monocyte migration mediated by chemoattractants have not been investigated.

Therefore, the effects of histamine, diphenhydramine, the $\mathrm{H}_{1}$-receptor antagonist, and cimetidine, the $\mathrm{H}_{2}$-receptor antagonist, to attract human monocytes as measured by chemotaxis, were tested.

The chemotaxis of human peripheral blood monocytes was performed with the membrane filter method ${ }^{6)}$. Human peripheral blood from healthy adult donors was drawn into a heparinized syringe (final concentration 20 units $/ \mathrm{ml}$ ). The monocytes were separated by Ficoll-Paque (Pharmacia), washed with phosphate-buffered saline ( $\mathrm{pH} 7.2)$ and the mononuclear cells containing approximately $28 \%$ monocytes were suspended at $5 \times 10^{6}$ cells $/ \mathrm{ml}$ in Gey's balanced salt solution containing $2 \%$ bovine serum albumin and $20 \mathrm{mM}$ HEPES (Nakarai) and added to the upper wells of the micro-chemotaxis chambers (Neuro Probe). The cells were separated from $10^{-8} \mathrm{M}$ FMLP (Sigma) and the samples to be tested of the lower wells by a $5 \mu \mathrm{m}$ polycarbonate membrane filter (Neuro Probe). After a $90 \mathrm{~min}$ incubation at $37^{\circ} \mathrm{C}$ in a humidified incubator, the filters were removed from the chambers, stained and quantified. Chemotactic activity was ex- pressed as the mean number of migrating cells per oil immersion field of triplicate samples \pm 1 SE by counting the number of monocytes that had migrated through the filter at 20 random oil immersion fields for each sample. Histamine (Nakarai) as the varying concentrations of $10^{-7} \mathrm{M}$ to $10^{-4} \mathrm{M}$ resulted in a significant inhibition of monocyte chemotaxis at $10^{-5} \mathrm{M}$, and at $10^{-6} \mathrm{M}$, inhibition was frequently noted (Fig. 1).

The effect of histamine on tissues can be blocked by antagonists that are thought to bind to two classes of cell surface receptors for histamine, which are designated $\mathrm{H}_{1}$ and $\mathrm{H}_{2}{ }^{7)}$.

To determine if monocytes have a surface receptor for histamine, the effects of the $\mathrm{H}_{1}$ receptor antagonist, diphenhydramine, and the $\mathrm{H}_{2}$-receptor antagonist, cimetidine upon histamine-induced inhibition of monocyte chemotaxis was examined.

The depressed monocyte chemotaxis in the presence of $10^{-5} \mathrm{M}$ histamine was restored by the addition of $10^{-5} \mathrm{M}$ cimetidine (Smith, Kline \& Fujisawa).

However, there was no effect by $10^{-5} \mathrm{M}$ diphenhydramine (Iwaki) of histamine-induced inhibition of monocyte chemotaxis to FMLP (Table 1), and at $10^{-4} \mathrm{M}$ of diphenhydramine tested gave the same results. In addition, diphenhydramine or cimetidine alone did not affect monocyte chemotaxis.

It was concluded that histamine-induced inhibition of monocyte chemotaxis mediated by chemoattractant depend on the $\mathrm{H}_{2}$ receptors, since the action of histamine was reversed by $\mathrm{H}_{2}$ but not by $\mathrm{H}_{1}$-receptor antagonist. 


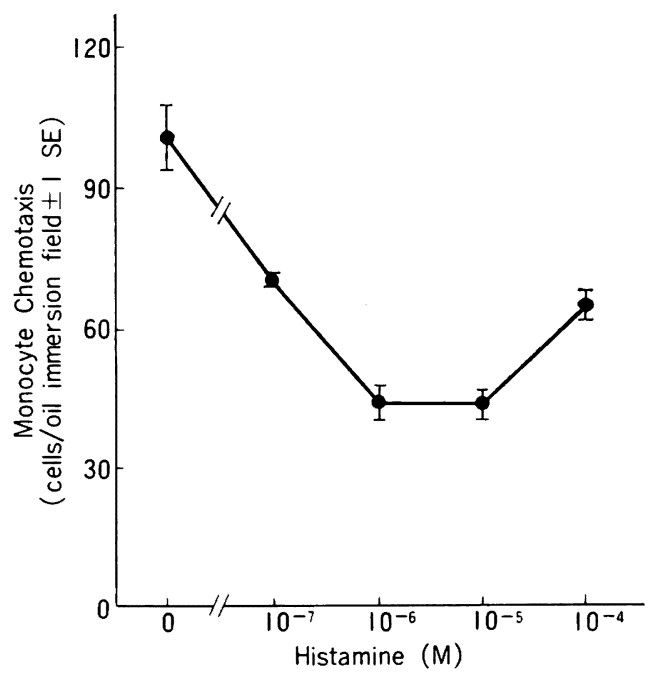

Fig. 1

Table 1 Effects of Histamine, Diphenhydramine and Cimetidine on Monocyte Chemotaxis

\begin{tabular}{lc}
\hline \multicolumn{1}{c}{ Agent added } & $\begin{array}{c}\text { Monocyte } \\
\text { Chemotaxis } \\
\text { (cells/oil immersion } \\
\text { field } \pm 1 \text { SE) }\end{array}$ \\
\hline Control & $10 \pm 2$ \\
FMLP & $109 \pm 1$ \\
FMLP & \\
+ Histamine $10^{-5} \mathrm{M}$ & $39 \pm 3$ \\
FMLP & \\
+ Histamine $10^{-5} \mathrm{M}$ & \\
+ Diphenhydramine $10^{-5} \mathrm{M}$ & $42 \pm 4$ \\
FMLP & \\
+ Histamine $10^{-5} \mathrm{M}$ & \\
+ Cimetidine $10^{-5} \mathrm{M}$ & $101 \pm 6$ \\
\hline
\end{tabular}

Thus, histamine would be involved in the modulation of monocyte chemotaxis in the inflammation such as gingivitis.

\section{References}

1) Clark, R. A. F., Gallin, J. I. and Kaplan, A. P.: The selective eosinophil chemotactic activity of histamine. J. Exp. Med. 142: 14621476, 1975.

2) Turnbull, L. W., Evans, D. P. and Kay, A. B.: Human eosinophils acidic tetrapeptides (ECFA) and histamine. Immunology 32: 57-63, 1977.

3) Clark, R. A. F., Sandler, J. A., Gallin, J. I. and Kaplan, A. P.: Histamine modulation of eosinophil migration. J. Immunol. 118: 137-145, 1977.

4) Lett-Bown, M. A. and Leonard, E. J.: Histamine-induced inhibition of normal human basophil chemotaxis to C5a. J. Immunol. 118: 815-818, 1977.

5) Anderson, R., Glover, A. and Rabson, A. R.: The in vitro effects of histamine and metiamide on neutrophil motility and their relationship to intracellular cyclic nucleotide levels. J. Immunol. 118: 1690-1696, 1977.

6) Foon, K. A., Wahl, S. M., Oppenheim, J. J. and Rosenstreich, D. L.: Serotonin-induced production of a monocyte chemotactic factor by human peripheral blood leukocytes. J. Immunol. 117: 1545-1552, 1976.

7) Black, J. W., Duncan, W. A. M., Durant, C. J., Ganellin, C. R. and Parsons, E. M.: Definition and antagonism of histamine $\mathrm{H}_{2}$-receptors. Nature 236: 385-391, 1972. 